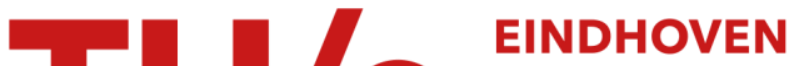 UNIVERSITY OF TECHNOLOGY
}

\section{Bubble behaviour on and mass transfer to an oxygen-evolving transparent nickel electrode in alkaline solution}

\section{Citation for published version (APA):}

Janssen, L. J. J., Stralen, van, S. J. D., \& Barendrecht, E. (1984). Bubble behaviour on and mass transfer to an oxygen-evolving transparent nickel electrode in alkaline solution. International Journal of Hydrogen Energy, 9(10), 849-853. https://doi.org/10.1016/0360-3199(84)90141-1

DOI:

10.1016/0360-3199(84)90141-1

Document status and date:

Published: 01/01/1984

\section{Document Version:}

Publisher's PDF, also known as Version of Record (includes final page, issue and volume numbers)

\section{Please check the document version of this publication:}

- A submitted manuscript is the version of the article upon submission and before peer-review. There can be important differences between the submitted version and the official published version of record. People interested in the research are advised to contact the author for the final version of the publication, or visit the $\mathrm{DOI}$ to the publisher's website.

- The final author version and the galley proof are versions of the publication after peer review.

- The final published version features the final layout of the paper including the volume, issue and page numbers.

Link to publication

\section{General rights}

Copyright and moral rights for the publications made accessible in the public portal are retained by the authors and/or other copyright owners and it is a condition of accessing publications that users recognise and abide by the legal requirements associated with these rights.

- Users may download and print one copy of any publication from the public portal for the purpose of private study or research.

- You may not further distribute the material or use it for any profit-making activity or commercial gain

- You may freely distribute the URL identifying the publication in the public portal.

If the publication is distributed under the terms of Article 25fa of the Dutch Copyright Act, indicated by the "Taverne" license above, please follow below link for the End User Agreement:

www.tue.nl/taverne

Take down policy

If you believe that this document breaches copyright please contact us at:

openaccess@tue.nl

providing details and we will investigate your claim. 


\title{
BUBBLE BEHAVIOUR ON AND MASS TRANSFER TO AN OXYGEN- EVOLVING TRANSPARENT NICKEL ELECTRODE IN ALKALINE SOLUTION
}

\author{
L. J. J. Janssen, S. J. D. van Stralen and E. Barendrecht \\ Eindhoven University of Technology, P.O. Box 513, 5600 MB Eindhoven, The Netherlands
}

(Received 14 February 1984)

\begin{abstract}
A theoretical description is given of a new model for mass transfer at gas-evolving electrodes where bubbles coalesce frequently. To check this model, both the thickness of Nernst diffusion layer and the bubble behaviour were determined for an oxygen-evolving transparent nickel electrode in $\mathrm{KOH}$ solutions under various electrolytic conditions. This electrode behaves like a gas-evolving electrode where bubbles coalesce frequently. It has been found that the mass transfer can be well described with the new model. Moreover, interesting results have been obtained on the degree of screening of electrode surface by adhered bubbles and the gas void fraction in a solution layer at the gas-evolving electrode.
\end{abstract}

\section{INTRODUCTION}

The mass transfer at gas-evolving electrodes has been intensively studied over the last fifteen years. Interesting surveys have been published by Ibl et al. [1] and by Vogt [2]. Two types of gas-evolving electrodes are distinguished [3], namely the gas-evolving electrode where bubbles do not coalesce, and the one where bubbles coalesce frequently. The mass transfer of the first type, for instance a hydrogen-evolving electrode in alkaline solution, is described by the hydrodynamic model [4]. For the second type, for instance an oxygen-evolving electrode in alkaline solution, no useful model is available as yet.

In this article a new model (coalescence model) is proposed to describe mass transfer of indicator ions. To check the new model, the thickness of Nernst diffusion layer and the bubble behaviour were determined for an oxygen-evolving electrode in $\mathrm{KOH}$ solution under various electrolytic conditions. The results given in this paper have been published in detail [5].

\section{EXPERIMENTAL}

\section{Determination of the thickness of the Nernst diffusion} layer

A thermostatic H-type electrolytic cell (divided into two compartments) was used for all mass-transfer experiments. The horizontal test electrode also served as the bottom of the test compartment.

Transparent nickel electrodes (made by Philips) were used as test electrodes. A transparent electrode is prepared by vacuum deposition of $\mathrm{SnO}_{2}$ layer $7 \times 10^{-4} \mathrm{~mm}$ thick and an Ni layer $0.35 \times 10^{-4} \mathrm{~mm}$ thick on one side of a glass disc having a diameter of $46 \mathrm{~mm}$. This is followed by deposition of a $\mathrm{Cu}$ ring layer on the outer part of the $\mathrm{Ni}$ layer to solder-on a current conductor und achieve a uniform current distribution. The transparency of the test-electrode was about $12 \%$.

To determine the thickness of the Nernst diffusion layer, the procedure used is described in literature [3]. Experiments were carried out at various current densities of oxygen evolution $\left(0.1-70 \mathrm{kAm}^{-2}\right), \mathrm{KOH}$ concentrations (1, 4 and $6.8 \mathrm{M})$ and pressures (40$1000 \mathrm{kPa}$ ).

\section{Determination of parameters characterizing bubble behaviour}

To minimize the ohmic cell resistance, a similar $\mathrm{H}$ type electrolytic cell, however, without membrane was used. The temperature of solution in the cell was kept at $303 \mathrm{~K}$ by cooling with an air-blower or by heating with a lamp (Philips PF $800 \mathrm{R}, 1000 \mathrm{~W}$ ). This lamp was also used for illuminating the test electrode during filming.

An Olympus Inverted Microscope, Model CKP, Tr 1 (objective $5 \times$ and ocular $3 \times$ ) was used for the enlargements. Moving pictures were obtained with a Beaulieu Reflex Control R $16 \mathrm{~B}$ camera at 70 pictures per second.

An unused nickel transparent was cleaned by washing with $\mathrm{KOH}$ solution. The cleaned electrode was anodically polarized at $1.6 \mathrm{kA} \mathrm{m}^{-2}$ for about $2 \mathrm{~h}$, after which a series of experiments was started. Following a 5 -min polarization to reach steady state, the bubble-generating transparent electrode was filmed.

The bubble behaviour was investigated at various current densities of oxygen evolution $\left(0.1-6.5 \mathrm{kA} \mathrm{m}^{-2}\right)$, $\mathrm{KOH}$ concentrations $(1-6.8 \mathrm{M})$ and pressures $(40-$ $700 \mathrm{k} \mathrm{Pa}$ ). 


\section{RESULTS}

\section{Thickness of the Nernst diffusion layer}

The thickness of the Nernst diffusion layer $\delta$ for indicator ions at an oxygen-evolving electrode in $1 \mathrm{M} \mathrm{KOH}$ at $298 \mathrm{~K}$ is practically the same for various electrode materials, viz. Pt, Ni and glassy carbon [3]. For almost all electrode materials [3] the $\log \delta / \log i_{\mathrm{O}_{2}}$ curve at $i_{\mathrm{O}_{2}}>0.2 \mathrm{kA} \mathrm{m}^{-2}$ is a straight line; its slope is mostly about -0.8 . It was found that the slopes of the $\log \delta / \log i_{\mathrm{O}_{2}}$ curves for both the transparent nickel and the nickel plate electrode were practically the same but that the values of $\delta$ were very different. $\delta$ for a nickel plate electrode in $4 \mathrm{M} \mathrm{KOH}$ at $298 \mathrm{~K}$ was about a factor of 4 smaller than that for a transparent nickel electrode under the same electrolytic conditions.

It was found that for a new transparent nickel electrode the $\mathrm{KOH}$ concentration has no effect upon the slope $h$ of the $\log \delta / \log i_{\mathrm{O}_{2}}$ curve $(h=-0.75)$ but, on the other hand, $\delta$ for $1 \mathrm{M} \mathrm{KOH}$ is about $60 \%$ larger than $\delta$ for $6.8 \mathrm{M} \mathrm{KOH}$. In Fig. $1, \log \delta$ is plotted versus $\log i_{\mathrm{O}_{2}}$ for an aged transparent nickel electrode at various pressures. This figure shows that the absolute value of slope $h$ increases slightly with increasing pressure.

The effect of pressure upon $\delta$ was investigated for two transparent electrodes with different degrees of ageing. The experiments showed that $\delta$ decreases with increasing electrode age whereas the slope of the $\log \delta / \log P$ curve does not depend on the degree of ageing. This slope is about 0.15 at pressures below about $3 \times 10^{5} \mathrm{~Pa}$ and about 0.30 at pressures above $c a$ $3 \times 10^{5} \mathrm{~Pa}$. For a transparent nickel electrode in $1 \mathrm{M} \mathrm{KOH}$ it has been found that $\delta$ was about $20 \%$ lower after 3 days than after $1 \mathrm{~h}$ of keeping in $1 \mathrm{M} \mathrm{KOH}$. The density of bubbles at the start of anodic polarization

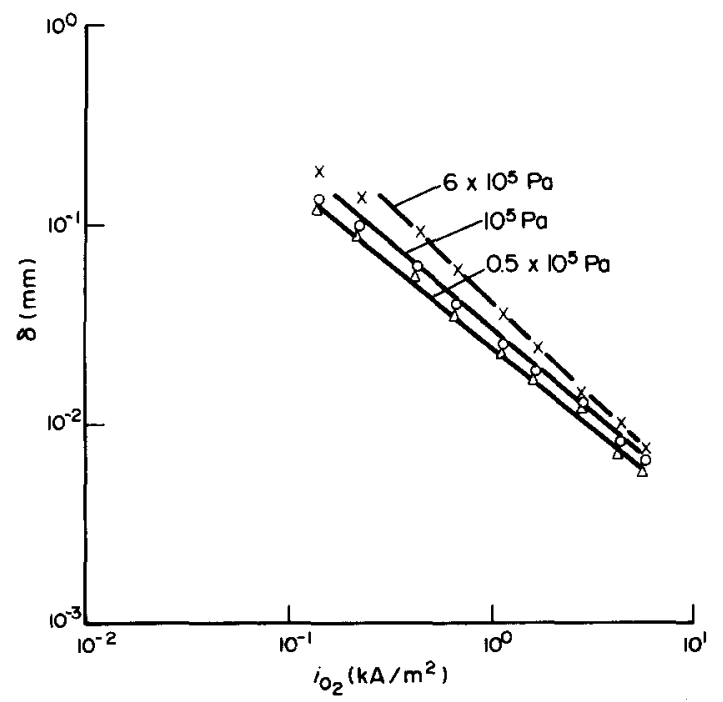

Fig. 1. Plot of $\log \delta$ vs $\log i_{\mathrm{O}_{2}}$ for the aged transparent nickel electrode $1 \mathrm{M} \mathrm{KOH}$ at $303 \mathrm{~K}$ and at pressures of $0.5 \times 10^{5}, 10^{5}$ and $6 \times 10^{5} \mathrm{~Pa}$. was about $3 \mathrm{~mm}^{-2}$ after $1 \mathrm{~h}$ in $1 \mathrm{M} \mathrm{KOH}$ and about $15 \mathrm{~mm}^{-2}$ after 3 days in $1 \mathrm{M} \mathrm{KOH}$.

\section{Characterization of oxygen bubble behaviour}

To characterize bubble behaviour on the electrode surface, the radius $R$ of each visible bubble present on an electrode surface varying between 1.3 and $6.3 \mathrm{~mm}^{2}$ was measured for a representative picture unless otherwise stated. Bubbles located below big ones were excluded. Even bubbles which have just left the electrode surface are easily distinguished from adhered bubbles thanks to the slight depth of field of the microscope and to the low speed at which the movie pictures were taken.

The sharpness of a bubble picture also depends on the rate of the increase of its radius. It has been found that bubbles with a radius of $10^{-2} \mathrm{~mm}$ were sharply pictured at $1 \mathrm{M} \mathrm{KOH}$ and atmospheric pressure and very foggy at $1 \mathrm{M} \mathrm{KOH}$ and high pressure $\left(6 \times 10^{5} \mathrm{~Pa}\right)$ as well at $6.8 \mathrm{M} \mathrm{KOH}$ and atmospheric pressure.

From the number of bubbles on a picture and the radius of each bubble we calculated the bubble density $n$, the average root of bubble radius $\left(R^{0.5}\right)_{a}$, the degree of screening of electrode surface by adhered bubbles $\theta_{s}=n S_{a}$, where $S_{a}$ is the average value of $\pi R^{2}$ and the root bubble radius distribution curve, showing the fraction of bubbles with a root of bubble radius below a fixed value.

The film clearly showed bubbles departing from the electrode surface. Almost all these detaching bubbles are formed by coalescence of two relatively big bubbles whose radius $R_{c}$ was determined. It was found that $\left(R_{c}^{0.5}\right)_{a} \approx R_{c, a}^{0.5}$ and $\left(n^{0.5}\right)_{a} \approx n_{a}^{0.5}$.

The relatively small bubbles taken up by a big one without formation of a directly departing bubble will not be taken into account in the determination of $R_{\mathrm{c}, a}^{0.5}$.

Differences in nature of electrode surface. Preliminary experiments showed that the bubble density on a transparent nickel electrode decreases at a decreasing rate as a function of time of electrolysis and is affected strongly by current interruption. Addition of a small quantity of indicator ions, viz. $\mathrm{Fe}(\mathrm{CN})_{6}^{4-}$ corresponding to the concentration used at the mass transfer measurements had practically no effect on the bubble density, when the current used for $\mathrm{Fe}(\mathrm{CN})_{6}^{4-}$ oxidation was taken into account.

Moreover, the bubble density increased considerably with the time the transparent nickel electrode is kept in a $\mathrm{KOH}$ solution. A transparent nickel electrode in $1 \mathrm{M} \mathrm{KOH}$ and with a bubble density lower than about $50 \mathrm{~mm}^{-2}$ at $1.6 \mathrm{kA} \mathrm{mm}^{-2}, 303 \mathrm{~K}$ and $10^{5} \mathrm{~Pa}$ was called a new transparent nickel electrode.

In the case that the bubble density was higher than about $50 \mathrm{~mm}^{-2}$, the electrode is considered as an aged transparent nickel.

Current density. Results for a new electrode in $1 \mathrm{M} \mathrm{KOH}$ and at atmospheric pressure and decreasing, as well as increasing, current density are given in Fig. 2. Below $0.5 \mathrm{kA} \mathrm{mm}^{-2}$ the nucleation of bubbles 

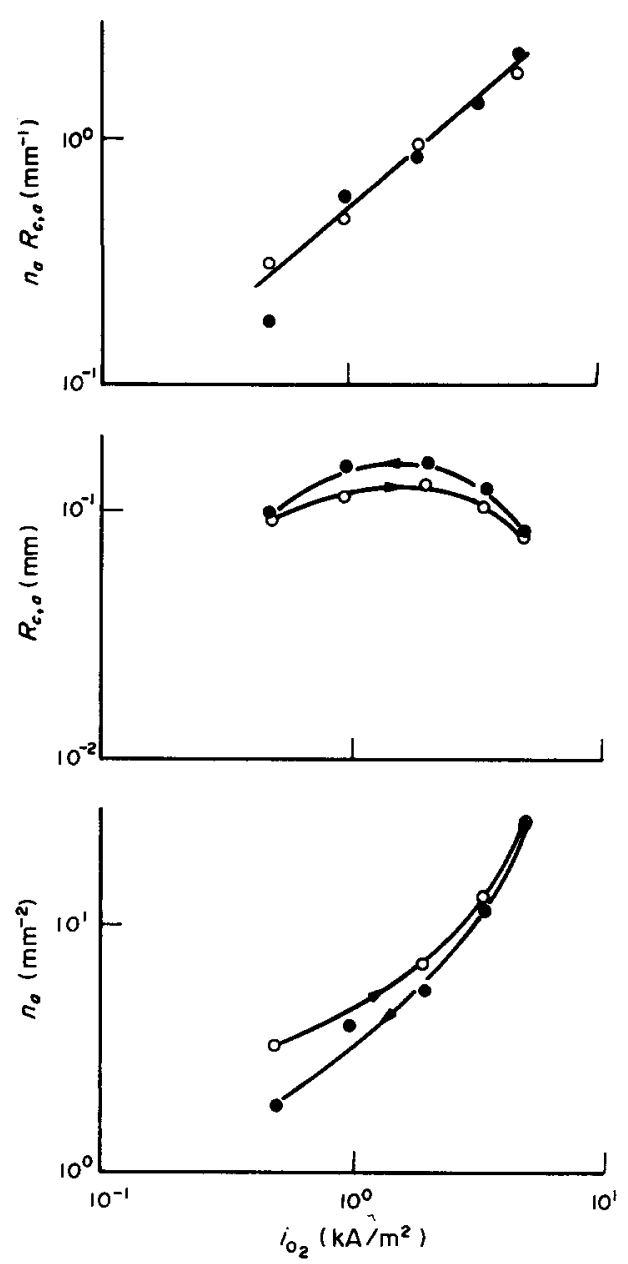

Fig. 2. The average bubble density, the average radius of coalescence bubble and $n_{a} R_{c, a}$ are plotted vs the current density of oxygen evolution for the new transparent nickel electrode $\mathrm{B}$ in $1 \mathrm{M} \mathrm{KOH}$ at $303 \mathrm{~K}$ and at atmospheric pressure. (Open points for series with increasing current density and closed points for series with decreasing current density).

occurred on certain scratches irregularly distributed across the electrode surface. Above $0.5 \mathrm{kA} \mathrm{m}^{-2}$ the bubble distribution was uniform.

Results for an aged electrode in $1 \mathrm{M} \mathrm{KOH}$ and at atmospheric pressure are analogously represented in Fig. 3 .

Bubbles with a radius of about $10^{-2} \mathrm{~mm}$ were foggy pictured; their radii could not be determined accurately and were taken equal to $10^{-2} \mathrm{~mm}$. Only when bubbles with a radius greater than $2.5 \times 10^{-2} \mathrm{~mm}$ were considered it was found that for an aged electrode $n_{a} R_{c, a}$ is practically independent of the current density.

Particularly in the case of the two highest current densities very big bubbles were present on the electrode surface. The pictures clearly showed that the density
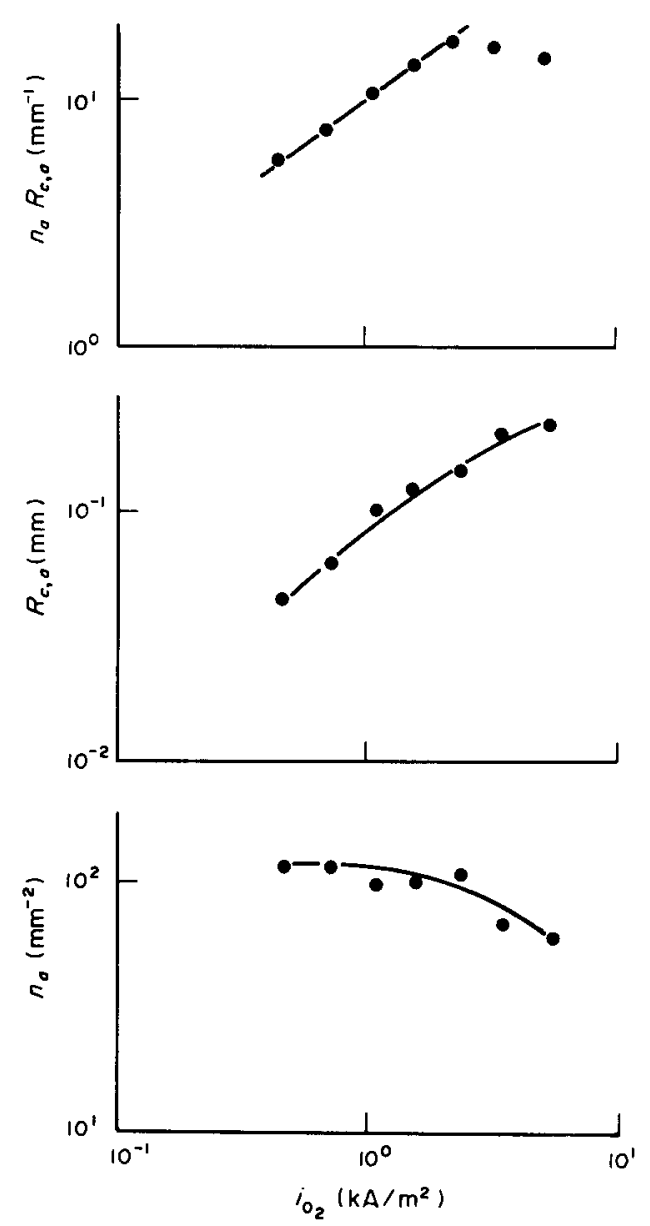

Fig. 3. The average bubble density, the average radius of coalescence bubble and $n_{a} R_{c, a}$ are plotted vs the current density of oxygen evolution for the aged transparent nickel electrode $\mathrm{D}$ in $1 \mathrm{M} \mathrm{KOH}$ at $303 \mathrm{~K}$ and at atmospheric pressure. (Results are given only for series with decreasing current density).

of small adhered bubbles present under big bubbles was comparable to the density for the other part of electrode.

For pictures with relatively few big bubbles the average observed density of bubbles was $113 \mathrm{~mm}^{-2}$ at the two highest current densities. When taking into account the small bubbles under the big one the density of bubbles is practically independent of current density. This means that the correct slope of $\log n_{a} R_{c}, a / \log i_{\mathrm{O}_{2}}$ curve is equal to that of the straight line drawn in Fig. 3 , that is 0.75 .

Figures 2 and 3 show that the slope of $\log n_{a} R_{c, a} /$ $\log i_{\mathrm{O}_{2}}$ curve for both electrodes is almost the same despite a different relation between $n_{a}$ and $i_{\mathrm{O}_{2}}$. When adhered bubbles are taken into consideration the relation between $n_{a} R_{a}$ and $i_{\mathrm{O}_{2}}$ can be calculated. It has been found that the slope of $\log n_{a} R_{a} / \log i_{\mathrm{O}_{2}}$ is 0.45 for a new electrode and -0.11 for an aged electrode. 
Results for a new electrode in $1 \mathrm{M} \mathrm{KOH}$ and at a pressure of $6 \times 10^{5} \mathrm{~Pa}$ were obtained. In this case too, bubbles with a radius of about $10^{-2} \mathrm{~mm}$ were foggy pictured. It has been found that the $\log n_{a} R_{c}, a / \log i_{\mathrm{O}_{2}}$ curve at high pressure is a straight line with a slope being practically the same as those at atmospheric pressure. Moreover, for adhered bubbles $n_{a} R_{a}$ did not depend on $i_{\mathrm{O}_{2}}$.

For a new electrode at high pressure as well as for an aged electrode at atmospheric pressure the bubble density is almost independent of current density and has, moreover, the same value. It is likely that in both cases the bubble density has reached its maximum value, this being about $120 \mathrm{~mm}^{-2}$.

\section{Pressure}

Series of experiments with a new electrode in $1 \mathrm{M} \mathrm{KOH}$ at $303 \mathrm{~K}$ and $1.6 \mathrm{kA} \mathrm{m}^{-2}$ were carried out at increasing pressure.

It has been found that $n_{a}$ increases at an increasing rate with increasing pressure, and $n_{a} R_{c, a}$ is practically independent of pressure.
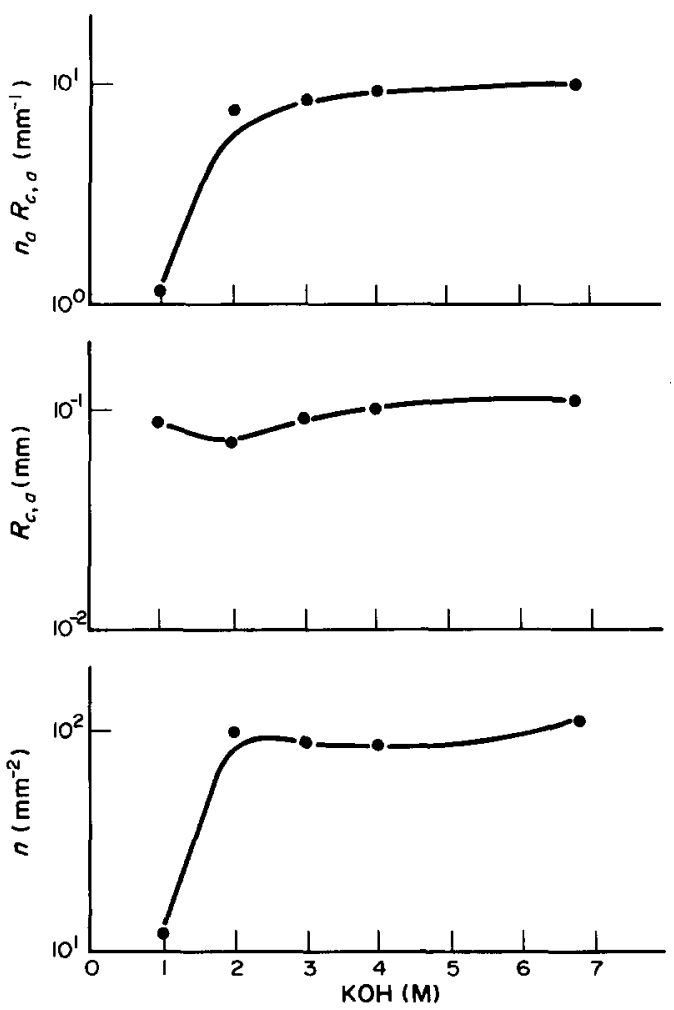

Fig. 4. The average bubble density, the average radius of coalescence bubble and $n_{a} R_{c, a}$ are plotted vs the KOH concentration for the new transparent nickel electrode $\mathrm{C}$ at $1.6 \mathrm{kA} \mathrm{m}^{-2}, 303 \mathrm{~K}$ and $10^{5} \mathrm{~Pa}$.

\section{$\mathrm{KOH}$ concentration}

A series of experiments was performed with a new electrode at increasing $\mathrm{KOH}$ concentration, the $\mathrm{KOH}$ solution was replaced after each experiment. Results are given in Fig. 4.

The bubble density increases up to a maximum value, that is about $100 \mathrm{~mm}^{-2}$. This agrees well with the maximum found for an aged electrode in $1 \mathrm{M} \mathrm{KOH}$ and atmospheric pressure and for a new electrode in $1 \mathrm{M} \mathrm{KOH}$ at a pressure of $6 \times 10^{5} \mathrm{~Pa}$.

The film showed that small bubbles translate across the electrode surface radially to big ones, whereupon they are absorbed. A just-formed big bubble only detaches after coalescence of at least two bubbles of comparable size.

\section{THEORY}

In this section a model is proposed to determine mass transfer of indicator ions from the bulk of electrolyte to a gas-evolving electrode where each detached bubble was formed, just before its detaching, by coalescence of two adhered bubbles of comparable size.

Mass transfer of indicator ions from the bulk of solution to the surface of a gas-evolving electrode is only discussed when the concentration of indicator ions at the electrode surface during gas evolution is practically zero.

The rate of mass transfer due to electrolyte flow caused by ascending bubbles can be obtained with the hydrodynamic model [4] and [6]. The rate of mass transfer according to the hydrodynamic model is characterized by the mass transfer coefficient $k_{k}$ or by the thickness $\delta_{h}$ of the Nernst diffusion layer $\delta_{h}=D_{i} / k_{h}$.

Only coalescing bubbles directly forming detaching bubbles are taken into consideration. After the disappearance of a coalescence bubble a quantity of fresh solution with a concentration equal to that of the bulk flows into the Nernst diffusion layer having a thickness $\delta_{h}$.

This results in an additional mass transfer of indicator ions to the electrode surface. Evidently, the mass transfer due to coalescence of bubbles and that due to ascending bubbles considerably affect each other.

Moreover, it is assumed that directly after disappearance of a coalescence bubble of diameter $R_{c}$, an electrode surface area of $\pi f R_{\mathrm{c}}^{2}$ comes in contact with fresh solution. Consequently, the cylindrical volume element perpendicular to this electrode surface area then has a concentration of indicator ions equal to $c_{0}$.

After a certain time a new bubble formed on this area disappears, whereupon this area again comes into contact with fresh solution. This phenomenon is constantly repeated after a period $\tau$.

To obtain the rate of mass transfer to electrode surface due to coalescence of bubbles various simplifications are still made. These are:

(1) the radius $R_{c}$ of all coalescence bubbles is equal; 
(2) the bubble density $n$ over the whole electrode surface is constant;

(3) an electrode surface area $\pi f R_{c}^{2} N$ per unit geometric electrode surface and per unit time comes into contact with fresh solution with an indicator ion concentration $c_{0, i}$, where $N=n / \tau$;

(4) the number of coalescence bubbles $N$ per unit geometric electrode surface and per unit time is equal to $3 v / 4 \pi R_{c}^{3}$; consequently $\tau=4 \pi R_{c}^{3} n / 3 v$.

The mass transfer coefficient $k_{c}$ due to coalescence of bubbles during time $\tau$ is calculated from Cottrell's equation. The migration of indicator ions is neglected due to an excess of supporting electrolyte in solution. From the equation of Cottrell it follows that

$$
\begin{aligned}
k_{c}=\pi^{1 / 2} f R_{c}^{2} \tau^{-1} n D_{i}^{1 / 2} \int_{0}^{\tau} t^{-1 / 2} \mathrm{~d} t & \\
= & 2 \pi^{1 / 2} f R_{c}^{2} n D_{i}^{1 / 2} \tau^{-1 / 2} .
\end{aligned}
$$

Substituting $\tau=4 \pi R_{c}^{3} n / 3 v$ into (1), after rearrangement, gives

$$
k=1.7 f R_{c}^{1 / 2} n^{1 / 2} D_{i}^{1 / 2} v^{1 / 2} .
$$

Since $\delta_{c}=D_{i} / k_{c}$ it follows from (2) that

$$
\delta_{c}=0.6 f R_{c}^{-1 / 2} n^{-1 / 2} D_{i}^{1 / 2} v^{-1 / 2} .
$$

When the mass transfer at a gas-evolving electrode is determined by a combination of solution flow induced by ascending bubbles with one induced by coalescing bubbles it may be assumed as a first approximation that the total mass-transfer coefficient $k=k_{c}+k_{h}$.

\section{DISCUSSION}

Verification of proposed model for mass transfer of indicator ions

Comparing the experimental dependences of $h$ on current density, $\mathrm{KOH}$ concentration, pressure and age of electrode for nickel plate and transparent nickel electrodes [3], it follows that the results obtained with transparent electrodes are applicable to metal-plate electrodes.

For the new model describing mass transfer of indicator ions to a gas-evolving electrode and assuming $f$ is a constant factor, relation (3) shows that $\delta_{c}$ is proportional to $\left(v n R_{c}\right)^{-0.5}$. In the new model only coalescing bubbles directly leading to detached bubbles are taken into account. Their radii varied; the greatest difference in bubble radius was a factor of about 2 . Owing to fluctuation in both $n$ and $R_{c}$, the factor $n_{a} R_{c, a}$ was determined to check the new model.

It has been found that for both new and aged electrodes in $1 \mathrm{M} \mathrm{KOH}$ at both atmospheric and high pressure the factor $n_{a} R_{c, a}$ is proportional to $i^{m_{1}}$ where $m_{1}$ varies between 0.6 and 0.8 . Consequently, taking into account this dependence of $n_{a} R_{c, a}$ on $i_{\mathrm{O}_{2}}$, it follows that $\delta_{c}$ should be proportional to $i_{\mathrm{O}_{2}}^{2}$ where $m_{2}$ varies between -0.8 and -0.9 assuming that $f$ is a constant factor and the rate of diffusion of dissolved oxygen into the bulk of solution is either negligible or proportional to $i_{\mathrm{O}_{2}}$.
Experimentally it has been found that, for transparent nickel electrode in $1 \mathrm{M} \mathrm{KOH}$ as supporting electrolyte, $\delta$ is proportional to $i_{\mathrm{O}_{2}}^{-0.75}$.

The new electrodes have a greatly different bubble behaviour at increasing current density (Figs 2 and 3). This difference, however, has no detectable influence upon both the slope of $\log n_{a} R_{c, a} / \log i_{\mathrm{O}_{2}}$ curve and the slope of $\log \delta / \log i_{\mathrm{O}_{2}}$ curve.

The effect of pressure upon $n_{a} R_{c, a}$ is practically negligible. From relation (3) it can be deduced that $\delta_{c}$ should then be proportional to $P^{0.5}$.

The experimental $\log \delta / \log P$ curve has a slope of 0.3 at high pressure and a slope of 0.15 at subatmospheric pressure.

The apparent difference between theoretical and experimental results may be explained by assuming that $f$ is a function of pressure, probably caused by slipping of bubbles across the electrode surface.

The effect of $\mathrm{KOH}$ concentration on $n_{a} R_{c, a}$ is clearly shown in Fig. 4. The factor $n_{a} R_{c, a}$ at $1 \mathrm{M} \mathrm{KOH}$ is about a factor of 3 smaller than that at $2 \mathrm{M}<(\mathrm{KOH})<6.8 \mathrm{M}$ for a new electrode (Fig. 4). Taking into account the dependence of diffusion coefficient of $\mathrm{Fe}\left(\mathrm{CN}_{6}^{4-}\right.$ on $\mathrm{KOH}$ concentration, it has been calculated that $D_{i}^{1 / 2} n_{a}^{-1 / 2} R_{c, a}^{-1 / 2}$ is $2.8 \times 10^{-2} \mathrm{~mm}^{3 / 2} \mathrm{~s}^{-1 / 2}$ at $1 \mathrm{M} \mathrm{KOH}$, $0.8 \times 10^{-2} \mathrm{~mm}^{3 / 2} \mathrm{~s}^{-1 / 2}$ at $4 \mathrm{MKOH}$ and $0.6 \times 10^{-2} \mathrm{~mm}^{3 / 2}$ $\mathrm{s}^{-1 / 2}$ at $6.8 \mathrm{M} \mathrm{KOH}$.

It has been found that $\delta$ at $1 \mathrm{M} \mathrm{KOH}$ is about a factor of 1.4 larger than that at $4 \mathrm{M} \mathrm{KOH}$ and about a factor of 1.5 larger than the one at $6.8 \mathrm{M} \mathrm{KOH}$. These differences are smaller than those between the calculated $D_{i}^{1 / 2} n_{a}^{-1 / 2} R_{c, a}^{-1 / 2}$ probably caused by a difference in the nature of transparent electrodes.

For an oxygen-evolving aged electrode in $1 \mathrm{M} \mathrm{KOH}$ at $6 \times 10^{5} \mathrm{~Pa}, 1.6 \mathrm{kA} \mathrm{m}^{-2}$ and $303 \mathrm{~K}$ the thickness of diffusion layer was determined after cinematographic experiments. Equalization of $\delta$ and $\delta_{c}$ calculated with relation (3) gives $f \approx 1.0$.

It may be concluded that the surface area of electrode coming into contact with fresh bulk-solution after detachment of a coalescence bubble is in the order of magnitude of its maximum cross-section. The preceding discussion shows that the proposal model is in fact useful in describing mass transfer of indicator ions to a gasevolving electrode where bubbles coalesce frequently.

\section{REFERENCES}

1. N. Ibl, E. Adam, J. Venczel and E. Schalch, ChemieIngr- Techn. 43, 202 (1971).

2. H. Vogt, Thesis, Stuttgart (1977).

3. L. J. J. Janssen, Electrochim. Acta 23, 81 (1978).

4. L. J. J. Janssen and E. Barendrecht, Electrochim. Acta 24, 693 (1979).

5. L. J. J. Janssen and S. D. J. van Stralen, Electrochim. Acta 26, 1011 (1981).

6. L. J. J. Janssen and J. G. Hoogland, Electrochim. Acta 18, 543 (1973). 